\title{
Development of Information and Communication Systems within the Building of Project-Oriented Manufacturing Organization
}

\author{
Anna Hamranova ${ }^{1}$, Stefan Marsina ${ }^{1}$, Pavol Molnar ${ }^{1}$, and Frantisek Okruhlica ${ }^{2}$ \\ ${ }^{1}$ University of Economics in Bratislava, Slovakia \\ (anna.hamranova, stefan.marsina, pavol.molnar) @euba.sk \\ ${ }^{2}$ Comenius University Bratislava, Slovakia \\ frantisek.okruhlica@fm.uniba.sk
}

\begin{abstract}
Project management (PM) has become a managerial discipline which is an inevitable prerequisite of managing modern business organizations, especially manufacturing ones. When applied properly it helps organizations to cope with permanently changing environment predominantly represented by customers, suppliers, competitors, and public authorities. Development of the project management methodology leads to increasingly effective implementation of strategic changes which is fundamental for being competitive on the marketplace. This PM development is in the center of building project orientation of an organization. But, developing just PM without development of overall organizational culture leads to low effectiveness of projects implemented in the organization. That is why development of projects and project management should be supported by development systems and areas of activities such as communications, knowledge, training and development of employees, and development of organizational standards and norms. The article focuses on the area of communication by using Business Intelligence systems.
\end{abstract}

Keywords: Project management, project-oriented organization, communications, knowledge, culture, Business Intelligence, project management office.

\section{Introduction}

Manufacturing companies more and more need projects and project management for being innovative, flexible, interoperable and efficient. Even quality standards take care of project management. For the field of project management the ISO 10006 standards represent a clear definition of a project as a process that brings a planned change.[5] However the use of projects in manufacturing organizations is known, it is less known, that the programs and projects are the outcomes of strategic thinking of top management of the organization. [7] Transition from strategic thinking to the particular act of strategy implementation is expressed in the following brief idea: A project starts when the management authorizes it. [10]

A project itself is not only a tool for technological or organizational innovation, but also a tool for generation of new managerial culture in the organization. 
Communication techniques applied in project teams enable mutual share of professional information which is essential for building a knowledge-based enterprise. Also techniques for saving information during the project, and at the end of it, offer possibilities to maintain the database of knowledge which is subsequently used for next events performed in the enterprise. The acquired knowledge has to be available for authorized people, so that the enterprise should develop organizational standards and norms for managing acquired know-how. All this mixed with purposeful training and development of the employees, who are important for providing core organizational activities, creates a ground for project orientation development.

The project-oriented organization becomes a significant issue in the strategic thinking of top managers today. Concerning the problem of getting right professional information in right time, the information flood coming from internet does not help sufficiently to increase the knowledge of specialists throughout the organization. Equally, it seems to be not satisfactory just to establish a position of chief communication, information, or knowledge officer in the enterprise without development of supporting relations and activities. The aim of this paper is to offer a model how to build project orientation in a business organization with focus on communication as one of supporting areas within this comprehensive process. This contribution has been elaborated on the basis of partial results of the research project VEGA 1/0933/14 supported by the Slovak Ministry of Education and Sport.

\section{Project Orientation of an Organization}

\subsection{Model of Building Project Orientation}

The low strategic thinking level of the top management in business organizations often reveals the orientation just on operational issues, short-term goals, and overlooking trends. This is very risky, and often leads to deep problems in near future. These organizations do not use projects for curing their systems problems, but they would like to take advantage of co-financing them by the European supporting funds. The evidence of this finding is available from results of an institutional VEGA research project carried out in 2005. [6] It must be stated, that it is a long-term run for such a poorly project-oriented organization to become a mature project-oriented one with developed programming. Also, the common professional effort of both managers and owners is a prerequisite. Owners usually have a majority in the Board of directors. If a company is to function professionally, it is very important that members of the board are properly skilled. [9] An integrated model of the process of becoming strategically highly developed project-oriented organization is suggested in Table 1: Integrated model of transformation process leading to the project-oriented organization. [8]

The model suggests that beside Project management development, which is in the center of the transformation process; there are other areas in the organization to be developed: Communications, Knowledge development, Training and development of 
employees, and Organizational standards \& norms. Table 1 shows the transformation of a current organization into a project-oriented one. Columns from left represent initial state of a company/organization, which is not yet developed in an area, and next five developing steps lead to a project-oriented, strategically mature organization.

The project development in Table1 starts from the state when projects, if any, are designed and implemented by external experts. No special organizational unit cares for this area. In most, this is a competence of one top manager or the functional manager authorized by him/her. Through the gradual involvement of internal personnel the enterprise establishes its own unit, a project management office, for the administration of design and implementation of projects.

The model was tested in real business environment independently by two diploma students while elaborating their theses. The first company was a manufacturing one operating in defense industry and its project-orientation in all areas oscillated on $3^{\text {rd }}$ step of development. The second company was mixed construction and consulting one, and its state of project-orientation development was in four areas at $4^{\text {th }}$ step and in knowledge development area at $5^{\text {th }}$ step.

\subsection{Communication and Knowledge Development Areas in an Organization}

Knowledge development inevitably goes concurrently with development of communication culture and training and development of employees. At first, the knowledge of employees is exclusively connected with their profession. They have no idea about what is done by their colleagues in the next functional area. For example, people in technical area have no concern for economy and vice versa. Solution of a multidisciplinary problem is almost impossible. The third step proposes an interdisciplinary approach of people working in professionally different areas. In the fourth step the multidisciplinary knowledge is acquired during the project preparation and/or implementation. The multidisciplinary work on the project and intensive communications enable participants to learn much about the profession of a partner within the project team. The supporting role of top management to make communications in team effective is expressed by Yeatts: The managers' behaviors and what they said were the means of conveying this support. [13] The fifth step describes the managed activities of the project management office where specialists share professional information with partners. The project management office is becoming a consulting center of the organization. [2] It can even become the publisher of a professional journal issued regularly minimum once a year.

The acquired knowledge has to be saved and properly stored for using by others later on. In the organization, the area covering standardization and normalization takes care of it. Thereby, knowledge generated from communication can be formalized and positively influences the behavior and overall culture of an organization. [12] 
Table 1. Integrated model of transformation process leading to the project-oriented organization

\begin{tabular}{|c|c|c|c|c|c|c|c|}
\hline $\begin{array}{l}\text { Initial } \\
\text { state }\end{array}$ & $\begin{array}{l}\text { Developed } \\
\text { area }\end{array}$ & Ist step & 2nd step & 3rd step & 4th step & 5th step & $\begin{array}{l}\text { Desired } \\
\text { state }\end{array}$ \\
\hline \multirow{5}{*}{ 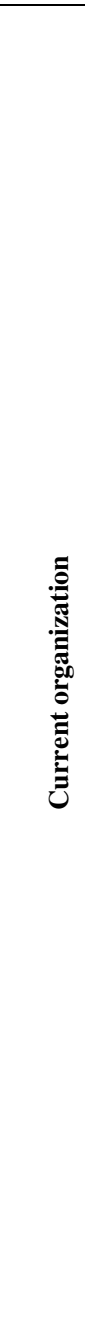 } & $\begin{array}{l}\text { Organization } \\
\text { al } \\
\text { standards \& } \\
\text { norms }\end{array}$ & $\begin{array}{l}\text { Standards \& } \\
\text { norms for } \\
\text { routine } \\
\text { processes }\end{array}$ & \begin{tabular}{|l} 
In general, \\
organizationa \\
1 norms \\
support \\
operation of \\
ICT and \\
T\&D of \\
employees
\end{tabular} & $\begin{array}{l}\text { Organization } \\
\text { al norms } \\
\text { include the } \\
\text { project } \\
\text { admini- } \\
\text { stration }\end{array}$ & $\begin{array}{l}\text { Organization } \\
\text { al norms } \\
\text { specified for } \\
\text { PM include } \\
\text { utilization of } \\
\text { Business } \\
\text { Intelligence } \\
\text { apps and } \\
\text { outsourcing } \\
\text { of selected } \\
\text { ICT }\end{array}$ & $\begin{array}{l}\text { Specific } \\
\text { norms } \\
\text { developed for } \\
\text { the Project } \\
\text { management } \\
\text { office } \\
\left(\text { PMO }^{*}\right)\end{array}$ & \multirow{5}{*}{ 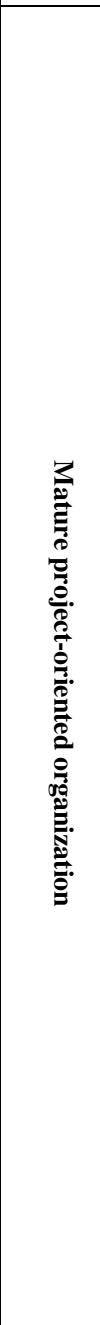 } \\
\hline & $\begin{array}{l}\text { Communicat } \\
\text { ions }\end{array}$ & $\begin{array}{l}\text { Communicati } \\
\text { on gaps } \\
\text { between } \\
\text { professional } \\
\text { areas and } \\
\text { managerial } \\
\text { levels }\end{array}$ & $\begin{array}{l}\text { Identification } \\
\text { of activi- } \\
\text { ties to be } \\
\text { supported by } \\
\text { IS/ICT }\end{array}$ & $\begin{array}{l}\text { Increased } \\
\text { horizontal } \\
\text { and vertical } \\
\text { cooperation, } \\
\text { start of } \\
\text { implementin } \\
\text { g BI } \\
\text { applications }\end{array}$ & $\begin{array}{l}\text { Development } \\
\text { of } \\
\text { communicati } \\
\text { on within the } \\
\text { project } \\
\text { teams; } \\
\text { optional use } \\
\text { of Business } \\
\text { Intelligence } \\
\text { applications }\end{array}$ & $\begin{array}{l}\text { Communicati } \\
\text { on of project } \\
\text { professionals } \\
\text { organized by } \\
\text { PMO }\end{array}$ & \\
\hline & $\begin{array}{l}\text { Knowledge } \\
\text { Development }\end{array}$ & $\begin{array}{l}\text { Knowledge } \\
\text { related to } \\
\text { profession } \\
\text { and position } \\
\text { in the } \\
\text { organization }\end{array}$ & $\begin{array}{l}\text { Knowledge } \\
\text { related not } \\
\text { only to } \\
\text { profession in } \\
\text { the } \\
\text { organization }\end{array}$ & $\begin{array}{l}\text { Creating } \\
\text { environment } \\
\text { for } \\
\text { interchanging } \\
\text { of tacit } \\
\text { knowledge }\end{array}$ & $\begin{array}{l}\text { Multidiscipli } \\
\text { nary } \\
\text { knowledge } \\
\text { acquired on } \\
\text { the project }\end{array}$ & $\begin{array}{l}\text { Shared } \\
\text { knowledge of } \\
\text { PM } \\
\text { professionals } \\
\text { (PMP**) } \\
\text { within the } \\
\text { projects or } \\
\text { PMO } \\
\text { (+ Journal) }\end{array}$ & \\
\hline & $\begin{array}{l}\text { Project } \\
\text { management } \\
\text { development }\end{array}$ & $\begin{array}{l}\text { Projects, if } \\
\text { any, designed } \\
\text { and } \\
\text { implemented } \\
\text { by } \\
\text { external } \\
\text { experts }\end{array}$ & $\begin{array}{l}\text { Projects are } \\
\text { designed and } \\
\text { implemented } \\
\text { prevailingly } \\
\text { by external } \\
\text { experts }\end{array}$ & $\begin{array}{l}\text { Projects are } \\
\text { designed and } \\
\text { implemented } \\
\text { prevailingly } \\
\text { by internal } \\
\text { experts }\end{array}$ & $\begin{array}{l}\text { Internal } \\
\text { experts are } \\
\text { gradually } \\
\text { certified as } \\
\text { PM } \\
\text { professionals } \\
\text { and Project } \\
\text { managers }\end{array}$ & \begin{tabular}{|l|} 
PMO \\
administers \\
design and \\
implementati \\
on of projects \\
including \\
pool of PM \\
experts
\end{tabular} & \\
\hline & $\begin{array}{l}\text { Training and } \\
\text { development } \\
\text { of employees }\end{array}$ & $\begin{array}{l}\text { T\&D only } \\
\text { in the } \\
\text { profession } \\
\text { given by } \\
\text { external } \\
\text { trainers }\end{array}$ & $\begin{array}{l}\mathrm{T} \& \mathrm{D} \text { only in } \\
\text { profession } \\
\text { given } \\
\text { prevailingly } \\
\text { by external } \\
\text { trainers }\end{array}$ & $\begin{array}{l}\text { T \& D of } \\
\text { mixed ex- } \\
\text { pertise given } \\
\text { prevailingly } \\
\text { by internal } \\
\text { trainers }\end{array}$ & $\begin{array}{l}\mathrm{T} \& \mathrm{D} \text { of } \\
\text { mixed ex- } \\
\text { pertise given } \\
\text { prevailingly } \\
\text { by internal } \\
\text { trainers or is } \\
\text { given within } \\
\text { the project }\end{array}$ & \begin{tabular}{|l|}
$\mathrm{T} \& \mathrm{D}$ of \\
mixed \\
expertise \\
given \\
prevailingly \\
by internal \\
trainers leads \\
to PMP \\
certification
\end{tabular} & \\
\hline
\end{tabular}

* PMO - Project Management Office, ** PMP - Project Management Professional

Source: own

\subsection{Communication Problems in the Manufacturing Organization}

Communications in an organization is a complex system of technically supported and non-technically supported communication. Non-technically supported communication is verbal or nonverbal (face-to-face). Information is exchanged between groups 
or individuals. Technically supported communication can be included to the information and communication systems known as IS/ICT. For the support of building or development of project orientation of an organization we must analyze both technically and non-technically supported communications.

In general, communication problems in the organization can be viewed from horizontal and vertical perspective. Fig. 1 shows a model of hierarchical and functional problems in communications within the organization.

Both phenomena - the hierarchical and functional communication gaps work simultaneously. The result is the creation of communication islands within which specialists operate. For example, it is clear that to improve the mutual behavior of partners in a supply chain in specific situations means actually the change of behavior of individual partners, i.e. the change of their culture. Definitely, it is a key process and not a short-term one. The developed communication systems should remove the communication gaps which are shown in Fig. 1.

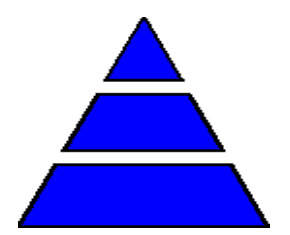

Communication gaps hierarchical

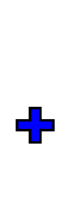

Communication gaps
functional
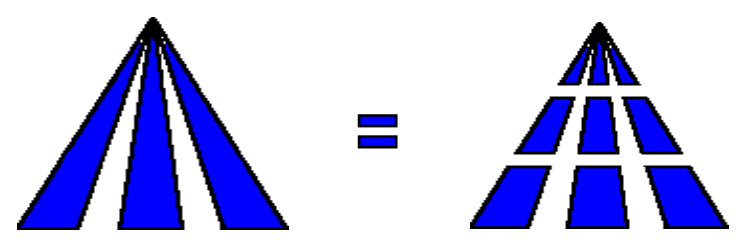

Communication isles

Fig. 1. Implications of bad hierarchical and functional communications in the organization (adapted by [4])

Another communication problem has been defined by Schulte. He calls it "Conflicts of goals between functional departments in the manufacturing company". [11] The functional departments especially in manufacturing organizations speak different professional languages and follow different goals. For example, marketing managers thing about wishes of customers, production managers about low costs, lead times and quality, research and development people thing about most modern design of products, and financial managers about investment and financial sources. One of the places where they can understand each other is a project team, because they share the same common goal.

\section{Business Intelligence Tools for the Development of Project- Oriented Manufacturing Organization}

The evolutionary maturity model of Business Intelligence applications is well compatible with the Model of development of a project-oriented organization.

On the basis of study several models concerned with maturity of Business Intelligence systems it has been found that each model is focused on the development of a 
specific part of Business Intelligence systems. For further research the BIMM (Business Intelligence Maturity Model) was developed initially by Gartner Company, then published by authors Chamoni \& Gluchowski. [1] This model was supplemented with elements from the TDWI (The Data Warehousing Institute) and Hewlett - Packard models. They served to determine the stages of BI maturity model evolution. Concurrently, criteria for measurement of maturity level of the individual enterprise were established. [3]

Starting from the above mentioned it is possible to describe BIMM as follows:

The BIMM consists of 5 levels, where each level covers 3 areas within which every level will be analyzed:

a) Business processes and reporting,

b) Information technologies,

c) Strategic management of an organization (the strategy in relation to BI)

\section{$1^{\text {st }}$ level - pre-defined reporting}

This level represents organizations, which start thinking about BI implementation, or those which have passed several bad starts and revalue they BI strategy.

\section{$2^{\text {nd }}$ level - BI within the professional departments}

Organizations on this level prefer manual solutions while creating analyses. They start planning and monitoring business processes, where they tend to apply new methods.

\section{$3^{\text {rd }}$ level - BI expansion to all areas of organization}

The third level of maturity model can be characterized by a need for integrating the subject or vertical oriented information solutions, which were implemented on the second level. Thereby organizations gain possibility to define metrics in more detail, e.g. metrics which require data from more than one area.

\section{$4^{\text {th }}$ level - expansion the number of users and decision making support}

Beside the top and middle management users of BI there is an extension of access for lower managerial levels of the organization, i.e. support of innovation and overall activity of employees.

\section{$5^{\text {th }}$ level - the active knowledge management}

The $5^{\text {th }}$ evolutionary level of the BIMM is characterized by activities related to integration of IS/ICT within the organization with other external systems all focused on increasing the value of business organization. The critical factor of success is the knowledge management principles application together with full support for Business Intelligence systems utilization.

According to published research [1,3] manufacturing companies' lag behind in Business Intelligence area compared to IT, financial and telecommunication companies. According to the BIMM the manufacturing companies reach only the 1 st. or 2 nd level maximally.

There are more suitable simpler and cheaper solutions for the manufacturing companies focused on basic business processes, whereas especially for small enterprises the BI solutions within information systems ERP (Enterprise Resource Planning), or the open source solutions are sufficient. 
Further research for possible improvement of Building project-oriented organization model will take into account the above mentioned achievements and the 5 levels of BIMM will be tested against the 5 levels/steps of the Project-oriented organization model.

\section{Conclusion}

To become a mature project-oriented manufacturing organization means to undergo a process which is based on strategic thinking and systems approach of the owners and executives. The aim of this contribution was to offer a model for manufacturing organizations presenting how to build the project orientation not only through developing projects and project management but also with support of other four activity areas development. This comprehensive approach ensures better the sustainability of high level project-orientation of the organization. Communication as one of the four supporting areas in this comprehensive process was discussed in more detail.

In manufacturing companies communication problems occur not only as hierarchical gaps but as extreme functional gaps caused by diversity of professional orientation of organizational units. Building of project-orientation can be a remedy.

\section{References}

1. Chamoni, P., Gluchowski, P.: Integrationstrends bei Business-Intelligence-Systemen Empirische Untersuchung auf Basis des Business Intelligence Maturity Model. In Wirtschaftsinformatik Ausgabe Nr. (February 2004)

2. Gareis, R.: Happy projects! Manz Verlag, Luchterhand, Stämpfli, Wien (2005)

3. Hamranova, A.: Aspekty implementácie Business Intelligence v slovenských podnikoch, pp. 41-47. Ekonóm, Bratislava (2013)

4. Kerzner, H.: Project Management. A Systems Approach to Planning, Scheduling, and Controlling, 9th edn. John Wiley and Sons, Inc., Hoboken (2006)

5. Lacko, B.: Strategic goals of project management. In: International Conference: Strategic Management and its Support by Information Systems. Technical University of Ostrava, Ostrava (2001)

6. Majtan, M., Marsina, S.: The evaluation of research questionnaire. In: Annual Report 2005 of the VEGA Research Project: Adaptation and Development Processes in Slovak Enterprises After the Slovak Republic Entry into European Union, Faculty of Business Management, University of Economics in Bratislava, Bratislava (2006)

7. Marsina, S.: Analýza pôvodu projektu v podnikovom prostredí. In: Economics, Finance and Management of Enterprise: Proceedings of the International Scientific Conference of the Faculty of Business Management, pp. 364-368. University of Economics, Bratislava (2003) (in Slovak)

8. Marsina, S.: Project Orientation Helps Business Organizations to Become Competitive. Economics and Management - the Scientific Journal of Faculty of Business Management, University of Economics in Bratislava, vol. 3 (2013)

9. Okruhlica, F.: The Responsibility of Boards is Unreplaceable. In: AmCham Connection. The Official Magazine of the American Chamber of Commerce in Slovakia, vol. 11, Bratislava (2006) 
10. Rosenau, M.D., Githens, G.D.: Successful Project Management - A Step-by-Step Approach with Practical Examples, 4th edn., p. 22. John Wiley \& Sons, Inc., Hoboken (2005)

11. Schulte, K.: Logistics, p. 78. Victoria Publishing, Prague (1994)

12. Thomasova, E.: Organizovanie, p. 112. Ekonóm, Bratislava (2007) (in Slovak)

13. Yeatts, D.E.,, Hyten, C.: High-performing self-managed work teams, p. 190. SAGE Publications, Inc., Thousand Oaks (1998) 